\title{
Industrialisation in Tanzania: The Fate of Manufacturing Sector Lies upon Policies Implementations
}

\author{
Emmanuel Simon Mwang'onda ${ }^{1, *}$, Steven Lee Mwaseba ${ }^{1}$, Mafuru Solomi Juma ${ }^{2}$ \\ ${ }^{1}$ Department of Rural Development and Regional Planning, Institute of Rural Development Planning (IRDP), Dodoma, Tanzania \\ ${ }^{2}$ Department of Environmental Planning, Institute of Rural Development Planning, Dodoma, Tanzania
}

Email address:

emwang'onda@irdp.ac.tz (E. S. Mwang'onda)

${ }^{*}$ Corresponding author

\section{To cite this article:}

Emmanuel Simon Mwang'onda, Steven Lee Mwaseba, Mafuru Solomi Juma. Industrialisation in Tanzania: The Fate of Manufacturing Sector Lies upon Policies Implementations. International Journal of Business and Economics Research. Vol. 7, No. 3, 2018 , pp. 71-78. doi: $10.11648 /$ j.ijber.20180703.14

Received: May 29, 2018; Accepted: July 4, 2018; Published: July 27, 2018

\begin{abstract}
It is undeniable fact that manufacturing sector plays key role in growth of any economy and it is from this sector developing countries can catch-up with the rest of the world. While other countries are struggling in upgrading the level of their industrialisation to accommodate the concept of sustainability by going for more advanced and green technology hence increase productivity, others are still on the ground struggling to take off and catch-up with industrialized world, Tanzania being one of them. In spite of various strategies proposed and implemented, the sector contribution has remained low, and currently statistics shows a decline. From analysis, it is evidently that manufacturing sector remain to be significant for the growth of Tanzania's economy despite her small GDP share relative to other sector like agriculture and service. The stagnant contribution share of sector is linked with; implementation lags on ambitious uncoordinated plans, slow transforming economic structure which is dominated by agriculture, and competition from low priced manufactured import from Asian economies. Thus, the best way to go is for a country to centrally coordinate all development policies to ensure connectivity and progressive monitoring of policies' implementations, and attention should be paid on agro-allied resource-based industries which are labor-intensive and value-adding which will ensure massive job opportunities to large agricultural population and take advantage of vast arable agricultural land available.
\end{abstract}

Keywords: Manufacturing, Economic Growth, Deindustrialisation

\section{Introduction}

It is undeniable fact that manufacturing sector plays key role in growth of any economy especially to those economies that are yet to be fully developed. It is from this sector developing countries can catch up with the rest of the world. Manufacturing industry make a room for innovation and growth of production technology, creation of massive employment especially in small and medium scale manufacturing industries like textile, food and beverage, and iron and steel industries $[1,2]$. If well connected with other sectors, manufacturing industries are not only large consumer of natural resources and of primary products, but also supplier of inputs to other medium and large scale industries thus support their growth and development [3-5].
Seemingly, in recent years as per $[3,6]$ contribution of the sector in world economy has declining, this is because of trend observed in most developed economies whereby deindustrialisation with shift of manufacturing industries to low income countries is experienced. Deindustrialisation is marked with a decline in employment share of the sector which is being replaced by service sector and advanced technology industries, which potentially increase productivity $[3,6]$.

However, the downward trend observed on the sector's contribution does not necessarily mean the same is experienced in developing countries. The sector shows no evidence of decline rather an increase in manufacturing value 
added share and increased manufacturing employment share, all of these positive trend owe thanks to South-East Asian economies whereby their increase offset that decline experienced in some other developing regions [3].

Given this situation it is suffice to say that, the role of the sector is still there in poverty eradication hence promoting sustainable development in the world, and what is happening in world economy is merely the reallocation of production focus, whereby most of these manufacturing industries which were in Europe and North America are now situation in developing countries in Asia, Latin America and Africa [5].

The twenty-first century manufacturing sector has been dominated by Asian Economies, Japan and later by Singapore, Indonesia, Malaysia, Taiwan and most recently Chinese economy [7]. These Asian tiger countries have become manufacturing hub for most of well know products and top brands in the world, thank to economies of scale enjoyed due to availability of relatively cheap and skilled labour, well stipulated investment policies and environment, availability of institutions ready for technological adoption and adaption, political will and support [8]. In Africa, few countries like Botswana, South Africa, and Mauritius have been doing well in this sector [3,9].

It is commended that structural and technological change brought by mature industries will allows developing economies to keep pace with development of the rest of developed world [3]. For the meantime, industrialisation dispersion is vividly seen between high income countries, rapid growing economies and low income economies, whereby while developed countries are going for higherdefinition technological industries taking on board sustainability concept, countries are struggling in upgrading the level of their industrialisation to accommodate the concept of sustainability by going for more advanced and green technology and become more competitive, some other are still on the ground struggling to take off toward industrialisation and catch-up with the rest of the world [7].

\subsection{Tanzania's Manufacturing Sector}

Even though industrialisation in Tanzania has become major and hot development agenda during fifth government presidency, the battle toward industrialisation has a long history.

The country has been emphasizing on industrialisation since its independence in 1961; firstly 1961-1967, under mixed economic system when private sector led the economy, the country embraced industries passed from colonial power, in which mostly were industries producing consumer goods especially food, beverage, and textile products and value adding processing industries aiming to feed manufacturing industries in Europe [10, 11].

Secondly under socialism era 1967 to 1985 before structural change of the economy, the country aimed at establishing import substituting kind of manufacturing industries. During this time, given the slow performance and low capacity of private sector during early independence years, the government decided to jump in with all feet and take control of the economy by nationalizing all major means of production, all operations of private sector in manufacturing, banking services and other services were seized. During this time the country attained industrial development level that has not been experienced again in history. Number of industrial firms rose from 220 during independence to more than 2000 in 1970, with 7000 registered trademarks, accompanied with rapid growth of manufacturing value added with capacity of meeting 70 percent of domestic demand for consumer goods and increase in absolute and relative labour productivity $[11,12]$.

Some of the action taken by the government while exercising its power over the economy include, price control aimed at limiting monopoly power of local producers, stringent regulations to monitor capital account, and fixed exchange rate. Unfortunately, good intention of the government to have full control over the economy started to adversely affect economic performance. The country started to experience negative macroeconomic performance and economic shocks from overvaluation of currency and forex shortage which hindered importation of industrial inputs. Together with oil crisis of 1973-74 and in 1978, extensive drought 1974-75 which eroded export of traditional cash crops such as sisal, cashew nuts, coffee and tea, a war with Uganda in 1979, high inflation of 30.2 percent in 1981 and negative balance of payment, the economy was hit badly so was manufacturing sector [10-13].

In the depth of crisis, negative real growth rate of economy was experienced in both 1981 and 1983, which necessitated the need for recovery programmes whereby efforts started with own recovery programmes [12]. In 1981-82 a National Economic Survival Programme was initiated with aim of resolving economic crisis using internal resources, and later 1982-83, in tackling the fiscal deficit problem, Structural Adjustment Programme was implemented [12, 14]. However, none of these programmes were successful in reviving the economy.

\subsection{Implementing Structural Adjustments}

The Structural Adjustment Programmes (SAP) and Economic Recovery Programmes (ERPs) under the supervision of Britton Wood institutions were implemented between 1986 and 1995 [12]. The programmes brought back the role of market in an economy by emphasizing on reduction of government control and involvement in investment and trading, and country's manufacturing sector was also reformed to allow private investors' involvement [11]. However, given the pace of growth of manufacturing sector in most developing countries during the time, and global trade liberalization, competitiveness of local industries was too low leading to significantly loss of local industries against competitive low cost imports $[11,12]$.

\subsection{Tanzania's New Industrial Era}

New era of industrialisation is marked by establishment and implementation of Sustainable Industrial Development 
Policy 2020 (SIDP), with a goal of having an industrial sector geared toward human development and job creation, economic transformation for achieving sustainable economic growth, environmental sustainability and equitable development [15]. The policy was to be implemented through three different phases; Phase I (1996-2000) a short term priority program focusing on rehabilitating and consolidating existing industries through capital financing and restructuring; Phase II (2000-2010) a medium term priority program aimed at having newly established intermediate goods and light capital goods and machinery industries, promote export manufacturing and taking into account emerging technological innovation to exploit country's natural resources; and Phase III (2010-2020) long term priority program aiming at consolidated industries came to exist in phase one and two, and provide major investment in basic capital goods [11, 12, 15]

Generally, structural adjustment and other development agenda adopted after 1995 were not in vein in rectifying the poor economic performance of the economy. Macroeconomic stability started to be observed through decline of inflation rate from 27 percent to less than 5 percent in 2002, revenue authority was introduced to enhance revenue collection to tackle fiscal deficit, addressing tax evasion and exemption problem whereby government revenue rose from 11 percent of GDP in 1993 to 13 percent in 1996 [14]. Improvement was also observed in financial services through increased effectiveness and branch network, increased leading to private sector, and manufacturing sector experience positive growth from increase of fish, minerals and other manufactured goods, and overall growth of economy increased from 3 percent in 1995 to 6 percent in 2002 [1214].

However, looking at Tanzania's manufacturing sector performance in comparison with other sectors in two decades, the sector has remained stagnant, in spite of various efforts and strategies proposed such as; adoption of development vision 2025 in 1999 focusing on industrial development, establishment of export processing zones (EPZs) 2003, and introduction of Integrated Industrial Development Strategy (IIDS) in 2010. Generally sector's contribution to GDP has remained low, and currently statistics shows a decline [10]. Does this stagnant and low contribution imply less importance of the sector towards growth of economy? Does the economy experience premature deindustrialisation? or is a country failing in implementation of its industrial development policies and strategies?

\section{Methodology}

The study employs regression analysis on time-series data for establishing significance of manufacturing industry toward growth and development of Tanzania's economy in answering the first two questions. Data were collected from well-known sources, such as Bank of Tanzania publications of major macroeconomic indicators, whereby from this source, quarterly provided data (2001Q1-2014Q1) ${ }^{1}$ on country's growth domestic products, and contribution of individual sectors like Agriculture, Fishing, Service, and Industry and Construction computed at market price were captured. Other source used was World Bank databank, whereby data on manufacturing value added share of GDP and its growth rate were captured from 1990-2016. While in answering the last question, a desk study is made to review implementation of Sustainable Industrial Development Policy (SIDP) 2020 adopted in 1996.

\section{Analysis Techniques}

\subsection{Preliminary Analysis}

Necessary test statistics were made on seasonal adjusted quarterly data of which all variables were integrated of order one I (1), to check for multicollinearity, serial correlation and heteroscedasticity to avoid spurious regression results. Results are indicated on table below:

Table 1. Preliminary Analysis.

\begin{tabular}{llll}
\hline $\begin{array}{l}\text { Regression } \\
\text { problem }\end{array}$ & $\begin{array}{l}\text { Method } \\
\text { employed }\end{array}$ & Test-statistics & Remarks \\
\hline Multicollinearity & $\begin{array}{l}\text { Variance Inflated } \\
\text { Factor (VIF) }\end{array}$ & Mean=1.11 $<10$ & $\begin{array}{l}\text { No } \\
\text { multicollinearity }\end{array}$ \\
$\begin{array}{l}\text { Test for Omitted } \\
\text { variable }\end{array}$ & $\begin{array}{l}\text { Ramsey RESET } \\
\text { test }\end{array}$ & $\mathrm{P}=0.2697>0.05$ & $\begin{array}{l}\text { No omitted } \\
\text { variable }\end{array}$ \\
Serial correlation & $\begin{array}{l}\text { Breusch-Godfrey } \\
\text { LM test }\end{array}$ & $\mathrm{P}=0.2024>0.05$ & $\begin{array}{l}\text { No serial } \\
\text { correlation }\end{array}$ \\
& $\begin{array}{l}\text { Breusch-Pagan } \\
\text { /Cook-Weisberg }\end{array}$ & $\mathrm{P}=0.9174>0.05$ & $\begin{array}{l}\text { Constant } \\
\text { Variance }\end{array}$ \\
Heteroscedasticity & test & & $\begin{array}{l}\text { Constant } \\
\text { Variance }\end{array}$ \\
\hline & White's test & $\mathrm{P}=0.6114>0.05$ & \\
\hline
\end{tabular}

From table 1 above, each variable included in a regression model had a Variance Inflated Factor (VIF) of 1.4, and the rule of thumb requires VIF to be more than 10 for multicollinearity to be declared present. While running a test for serial correlation and heteroscedasticity, at five percent significance level the null hypotheses is failed to be rejected, which imply our model has no serial correlation and it has constant variance.

\subsection{Significance of Manufacturing Sector}

Regression analysis is made for the major two reasons; i) to ascertain the importance/significance of the sector to the economy, so as ii) to test the first of the two conditions for deindustrialisation as put forward by Haraguchi, Cheng and Smeets (2016), whereby deindustrialisation is noted when significant of manufacturing sector declines giving way mostly to the high influence of service sector on employment and growth of the economy $[3,5]$.

1Data were obtained only for this period because of limitation on data availability that are consistent throughout. Thus continuation of the series was not possible because of huge difference in data (data source https://www.bot.go.tz/Publications/PublicationsAndStatistics.asp\#Statistics) 
Initial regression equation;

$$
G D P_{t}=\beta_{1}+\beta_{2} M A N_{t}+\beta_{3} A G R_{t}+\beta_{4} S E R V_{t}+\mu_{t} \ldots \ldots
$$

Whereby;

1. GDP $=$ Growth Domestic Product at constant 2001 prices

2. $\mathrm{MAN}=$ Manufacturing value added

3. $\mathrm{AGR}=$ Agriculture value added

4. $\mathrm{SERV}=$ Service (wholesale and retail, transport and communication, and financial intermediation)

5. $\mu=$ stochastic term

From the equation, the variable service is computed as summation of contribution made by transport and communication, wholesale and retail trade, and financial intermediation. As put forward by [3], at higher income when country starts to experience decreasing share of manufacturing, demand for services like logistics, financial intermediation, trade and information and communications technology rise a major drivers of economy [3].

To tackle the problem of stationarity and seasonal variation, the model was logarithm transformed and differenced, as follows;

$$
\Delta \log G D P_{t}=\beta_{1}+\beta_{2} \Delta \log M A N_{t}+\beta_{3} \Delta \log A G R_{t}+\beta_{4} \Delta \log S E R V_{t}+e_{t} \ldots \ldots
$$

Whereby;

$\Delta \log G D P_{t}=\log G D P_{t}-\log G D P_{t-4} ; \Delta \log A G R_{t}=$ $\log A G R_{t}-\log A G R_{t-4}$

$\Delta \log M A N_{t}=\log M A N_{t}-\log M A N_{t-4} ; \Delta \log S E R V_{t}=$ $\log S E R V_{t}-\log S E R V_{t-4}$

$e_{t}=$ error term

Table 2. Regression Results.

\begin{tabular}{lllll}
\hline Variable & Coefficient & Std. Err & $\boldsymbol{t}$ & $\boldsymbol{P}>/ \boldsymbol{t} /$ \\
\hline Manufacture & $0.1594 * * *$ & 0.054266 & 2.94 & 0.005 \\
Agriculture & 0.0823058 & 0.057823 & 1.42 & 0.162 \\
Service & $0.2624 * * *$ & 0.049325 & 5.32 & 0.000 \\
Constant & $0.0289 * * *$ & 0.006008 & 4.81 & 0.000 \\
\hline
\end{tabular}

The asterisks $* * *=$ significant at $1 \%$ level of significance

No. Observations $=49$

$\mathrm{F}(3,45)=15.16$

Prob $>\mathrm{F}=0.0000$

R-square $=0.5026$

From the table 2 above, coefficient of manufacturing exerts significant positive effect on gross domestic product, implying that one percent extra value added of manufactured products will bring about 0.15 percent growth in GDP holding other factors constant. Similar effects can be observed with service sector, whereby one percent increase in value of services brings 0.26 percent increase in GDP ceteris paribus. Comparing coefficients of services and manufacturing sector relative to their share on GDP for the 2001-2014 period, in which average share of service sector has been five times higher than that of manufacturing, the latter is doing far better than the former.

\subsection{The Share of Manufacturing on GDP and Employment Relative to Service Sector}

\subsubsection{Manufacturing Share on GDP Relative to That of Service}

The share of manufacturing value added on Tanzania's GDP has remained moribund in almost three decades, standing mostly at less than 10 percent, and given the trend observed since 1998, a year of highest percentage of 10.5 , the sector's share is declining reaching to 5.6 percent in 2016. Meanwhile the size of the sector's share is one-sixth relative to service sector (see table 3).

\begin{tabular}{|c|c|c|c|c|}
\hline $\begin{array}{l}\text { SIDP implementation } \\
\text { phases }\end{array}$ & Time bound & $\begin{array}{l}\text { Average manufacturing, } \\
\text { value added (\% of GDP) }\end{array}$ & $\begin{array}{l}\text { Average service, value } \\
\text { added (\% of GDP) }\end{array}$ & $\begin{array}{l}\text { Size of Manufacturing share } \\
\text { relative to Service }\end{array}$ \\
\hline I & $1996-2000$ & 9 & 43 & $1: 5$ \\
\hline II & 2001-2010 & 8 & 47 & $1: 6$ \\
\hline III & 2011-2016 on going & 7 & 43 & $1: 6$ \\
\hline
\end{tabular}

Table 3. The size of manufacturing value added share (\% GDP).

In comparison with service sector, manufacturing value added share of GDP is very minimal, as it can be observed from figure 1 below, its share has been within a very inner circle with not more than 10 percent share, meanwhile service sector share on GDP has been always above 30 percent but less than 50 percent, this situation is one of the signs of deindustrialisation in an economy [16]. In spite of its small share on GDP, manufacturing sector remained to be important for the growth of economy as indicated on regression results. 


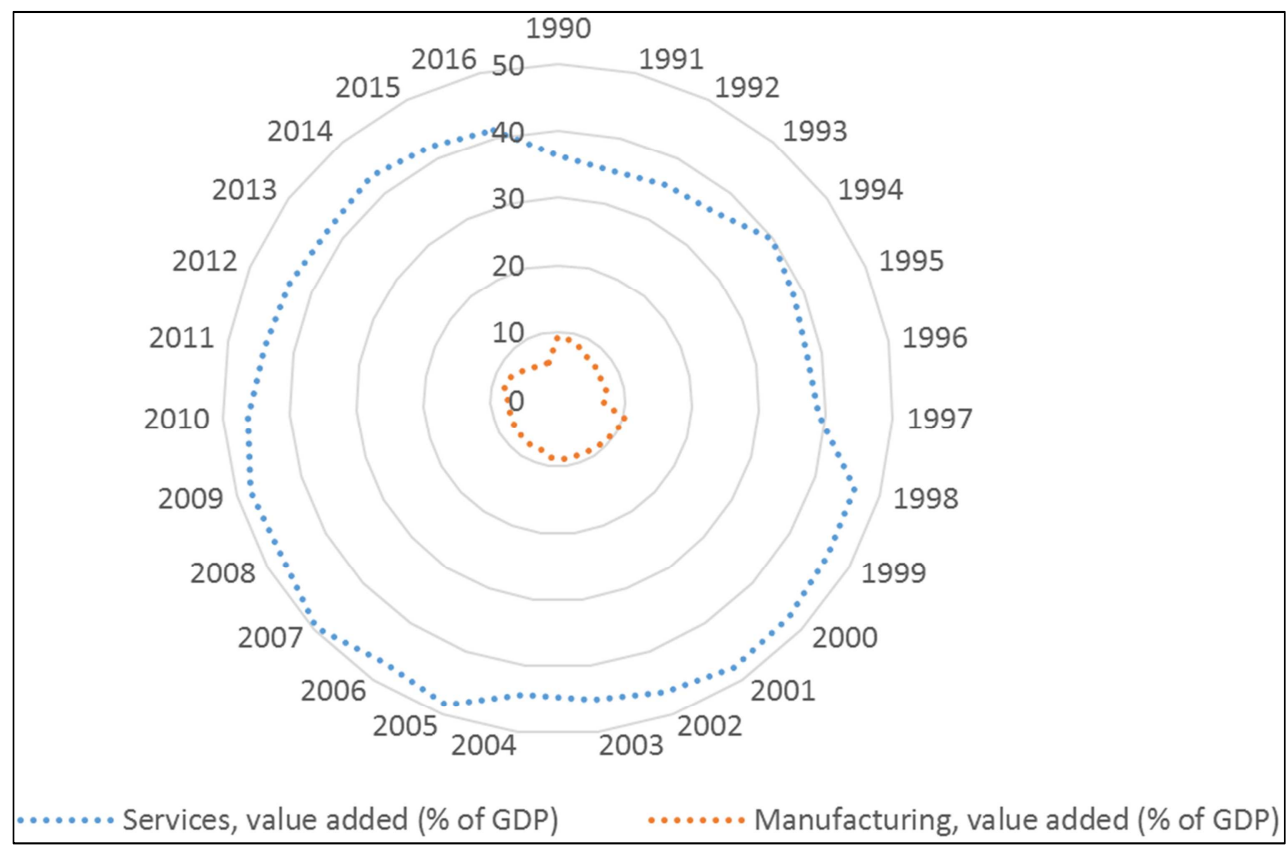

Data source: World Bank databank (2018)

Figure 1. Contribution of manufacturing value added (\% GDP) 1990-2016.

\subsubsection{Industrial Share on Employment}

Basically Tanzania's employment has been run mostly by agricultural sector, whereby it has managed to accommodate more than 70 percent of population for more than fifty years. But it has observed a decreasing trend giving way for other sector growth in employment share.

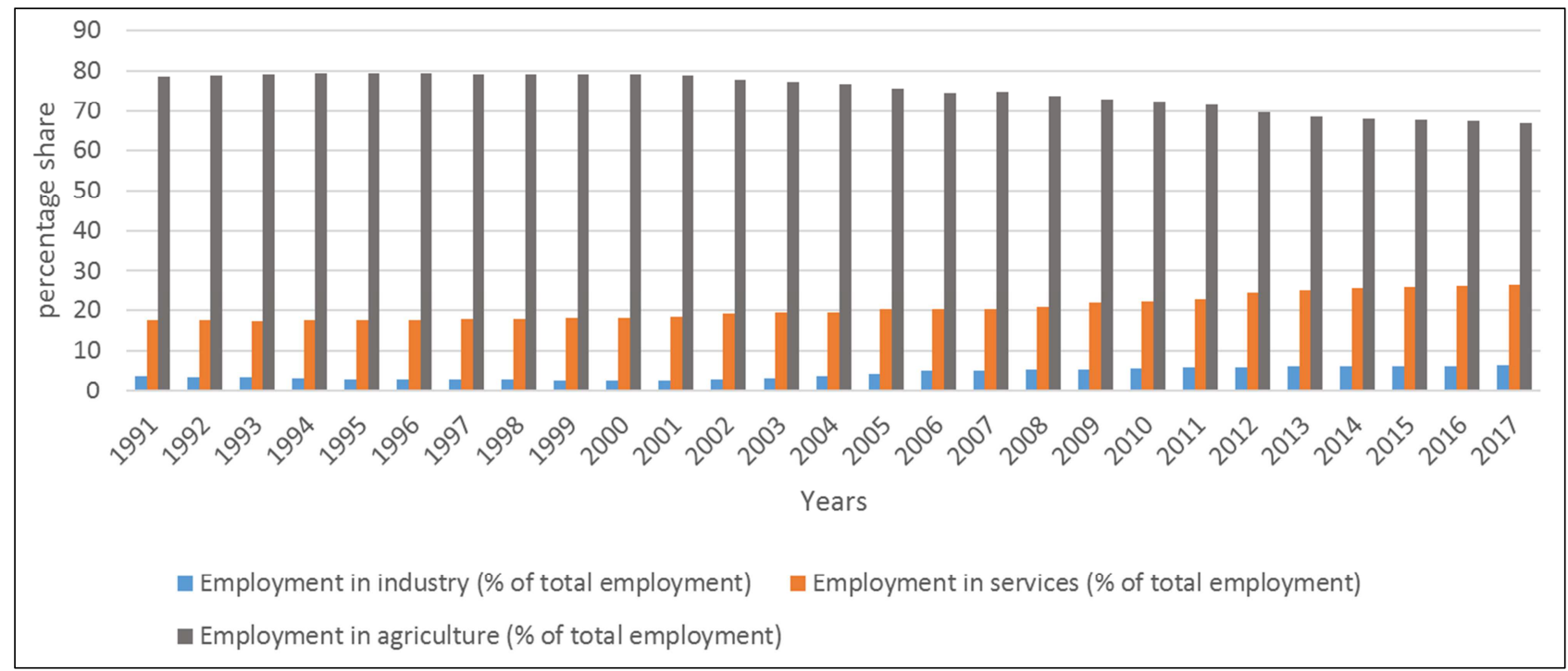

Data source: World Bank databank (2018)

Figure 2. Employment share of industry relative to other sector.

As the figure indicates, both service and industry sector show an increasing trend in employment share, whereby potential and significance growth of employment share for 20 years between 1996 and 2017 has been shown by industry sector which experienced more than double increase in its employment share from 2.9 percent in 1996 to 6.4 percent in 2017, which is equivalent to 121 percentage increase. Service sector grew by 50 percent during the same period from 17.7 percent to 26.7 percent. A 16 percent decline agriculture employment share is observed during the same time period. 


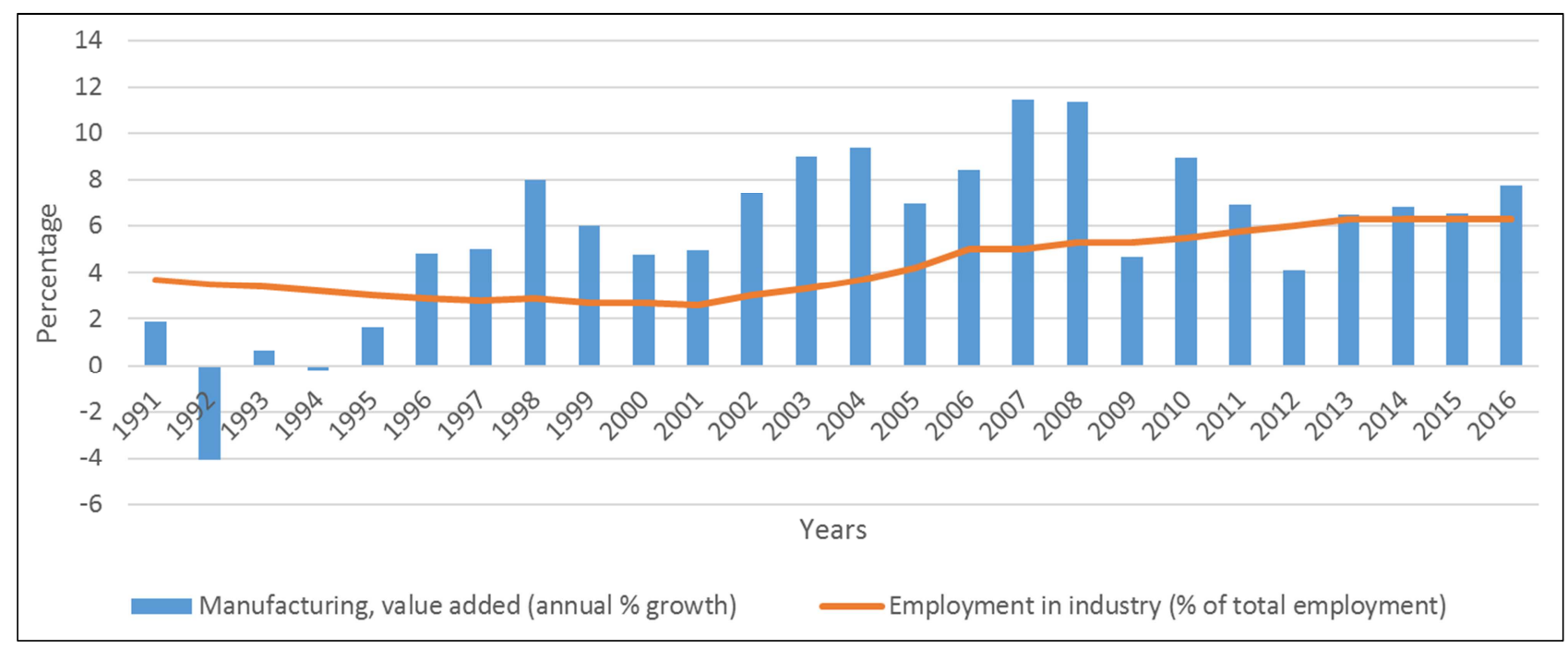

Data source: World Bank database (2018)

Figure 3. Annual growth of manufacturing share and employment share.

Employment share of the sector positively correlate with its annual growth, however its employment share has been more stable compared to fluctuations observed on own growth of the sector. A steady increase in employment share is observed from 3 percent in 2001 to 6 percent in 2016.

\section{Discussion}

In responding to the question of significance, there is no doubt that manufacturing sector remain to be significant for the growth of Tanzania's economy notwithstanding her small share on GDP relative to other sectors like agriculture and service, justified by regression results which show positive effect of sector on GDP both in short-run and long-run, at the same time, annual growth rate of the sector correlates positively with growth of her employment share. These results have great implication to the economy, that it is worthy a while to continue attracting more investment on manufacturing sector to boost its growth and increase its overall economic share. This does not ignore the fact of positive contribution from side of service sector on GDP and employment share as also presented by [6], that "manufacturing is not the only growth game in town. Services can also be dynamic and contribute to growth and jobs" [6].

A less than 10 percent share manufacturing has on GDP over a period of 25 years, may imply deindustrialisation as per [16], who described deindustrialisation in broad sense to be not only a decline in manufacturing share but rather a stable or increasing share but which is very less compared to that of service sector [16]. Tanzania has not yet exhausted the sector's full potential to start experiencing its deindustrialisation. According to [3], a country's manufacturing share of GDP need to reach at least 30 percent before it starts to diminish leaving a room for service sector and high tech-industries to take over [3]. A continuous decline in manufacturing share of GDP since 2011 from eight percent to five percent in 2016, and having a share that has always been less than 10 percent, has been associated with; implementation lags on ambitious plans with unrealistic goals [9, 10, 17], slow transforming economic structure which is dominated by agriculture [9, 12, 16, 17], and competition from low priced manufactured import from Asian economies [18].

Laxity implementations are regarded to be major setback toward industrialisation. Tanzania formulated its sustainable industrial development policy in 1996 which aimed at putting in place short-term and long-term strategies to elevate country's industrial level to middle income status by 2020 . However, drawing an experience from implementation of this policy, the country is lagging behind in achieving stated objectives within agreed period of time. The policy emphasized on making room for private sector to take lead in industrial development while the government embraces the role as enabler by; creating environment for easiness of doing business, fair trade practice, transparency, trade openness, and promotion of indigenous knowledge in entrepreneurship. The government was also responsible for establishing reliable infrastructure for power and water supply, transport network and communication services [15].

However, twenty years since its formulation, the economy is currently carrying-out activities that were supposed to have been carried-out in phase one of policy that is in 1996-2000 period. Phase one focused on restructuring, rehabilitating and consolidate existing industries, also on establishing agroallied industries which are resource-based through monetary and fiscal incentives to private sector [15]. However, sixteen years later, a country remained to suffer from imbalance international trade due to exports that are largely based on raw materials and low-value low tech products [19, 20]. Manufacturing sector's share on GDP remained lagging behind service sector, for example, in 1996 sector's share was 7 percent compare to 37 percent of service sector, in 2016 sector's share is even lesser compared to previous 
performance, standing at 5 percent compared to 41 percent of service sector.

It has also been observed that instead of large number of labour to move from low productive agricultural sector to high productive manufacturing sector which is labour intensive, the movement is seen to be toward services sector which is yet to be well developed to be able to accommodate existing employment pressure within an economy, leading to domination informal employment by more than 70 percent compared to 13 percent in formal employment [20,21].

In line with that, studies conducted during third phase of policy implementation (2010-2020) indicate a number of setbacks that were supposed to have been ironed out during phase one of policy. Such setbacks include; cost of doing business which is reported to be high with unfavourable environment for private sector investment. A country has been experiencing unreliable power supply whereby by 2006 a month average power cut was 71 hours, and improvement were made only to 58 hours in 2012, and from private firms' interview made by World Bank survey indicated major problems in 2013 were access to finance, access to electricity and higher tax rate [22]. These findings do not differ much with findings in year 2000, the study made by Confederation of Tanzania Industries (CTI) and Confederation of Danish Industries (DI) in highlighted utility costs and reliability, bureaucracy and taxes to be major setback for industrial development [23]. Thus, despite improvements that are observed in an economy, these changes come over a very long period of time which is out of implementations' target. For example it took 20 years that is between 1990 and 2010, for employment share of sector to double, from 1.4 percent to 2.7 percent [21]

Laxity implementations are also observed on phase two of the policy, whereby to fasten growth of export-led manufacturing industries, Export Processing Zone (EPZs) program was established in 2002, EPZ Act enacted in April 2002 , started to be effective on 2003, and operationalization of the program started three years later, that is in 2006 when Export Processing Zone Authority (EPZA) was formulated $[10,21,24]$. In spite of the formulation of export processing zones, which were later unified with Special Economic Zones (SEZs), it is noted that there is been slow performance of the program, whereby from 13 sites allocated for SEZs only one is operating, with not more than 50 producing firms, this being the results of "long delays in clarifying the institutional and regulatory regime" [21].

In sum, as pointed out in Tanzania Industrial competitiveness report of 2012, the economy is not experiencing premature deindustrialisation, rather a low level and stagnated industrial sector development which has yet to reach her full potential [25].

\section{Conclusion}

From time-series analysis and review made on an economy, suffice it to say that Tanzania's manufacturing sector remain to be significant for the growth of economy notwithstanding her small share on GDP relative to other sectors. However, the continuous low level share of sector on GDP is associated with; implementation lags on ambitious plans with unrealistic goals, slow transforming economic structure which is dominated by agriculture, and competition from low priced manufactured import from Asian economies.

\section{Recommendations}

A number of efforts are needed to be made to speed up industrial development of in the country, including;

Creation of industrial development framework which will be a road map to be observed by any government that will be in power irrespective of time. It has been pointed out by [25, $12,21]$ that one of failure of implementation of development policy was lack of implementation framework at early stage of policy inception [12, 21, 25].

Coordination and harmonization of all sectoral development policies, since industrialisation is possible only if interlink is made between sectors, such as having one ministry that is responsible of advocating, and overseeing implementation of development policies. This will allow easy monitoring and in time evaluation of policies' implementation and avoidance of having similar activities addressed by two different policies at different time intervals.

The best choice is to focus in one or two sectors in which a country can easily develop a comparative advantage. The current development in manufacturing sector is yet to bring significant job opportunities to Tanzanians because of focusing on capital-intensive resource based industries such extracting and construction industries in expense of traditional laborintensive manufacturing industries like textile and clothing [25]. Thus, given the current competitiveness of manufacturing sector globally, with an economy which is largely dependable on resource-based agricultural products with limited value addition, the focus may only be directed on agro-allied industries. The efforts should be on gaining competitiveness on adding value to agricultural products and establishment of textile and clothing industries which has advantage of reaching large part of population which are still in agriculture sector and with advantage of a country having largely potential arable agricultural land.

\section{References}

[1] D. Su and Y. Yao, "Manufacturing as the Key Engine Asian Development Bank Institute," Tokyo, 573, 2016.

[2] D. Kasenda, "Can Asian Developing Countries Stuck In A ' Middle-Income Trap ' Learn From South Korea's Economic Development Experience ?,” no. 6, pp. 1-16, 2015.

[3] UNIDO, Industrial Development Report 2016: The Role of Technology and Innovation in Inclusive and Sustainable Industrial Development. Vienna, 2015.

[4] V. Kathuria and R. R. Natarajan, "Is Manufacturing an Engine of Growth in India in the Post-Nineties?," J. South Asian Dev., vol. 8, no. 3, pp. 385-408, Dec. 2013. 
[5] N. Haraguchi, C. F. C. Cheng, and E. Smeets, "The importance of manufacturing in economic development: Has this changed?," World Dev., vol. 93, pp. 293-315, 2016.

[6] E. Ghani and S. O'Connell, "Can service be a growth escalator in low-income countries?," World Bank Policy Res. Work. ..., no. July, 2014.

[7] W. Naude and A. Szirmai, "The importance of manufacturing in economic development: Past, present and future perspectives," MERIT Work. Pap., no. 41, 2012.

[8] ASEAN, "ASEAN Investment Report 2015 Foreign Direct Investment and MSME Linkages," 2015.

[9] United Nations, "African Regional Implementation Review for the Commission on Sustainable Development ( CSD-14 ) Report on the Review of African Sustainable Industrial Development," African Reg. Implement. Rev. Comm. Sustain. Dev., no. January, 2006.

[10] S. Wangwe, D. Mmari, J. Aikaeli, N. Rutatina, T. Mboghoina, and A. Kinyondo, "The Performance of the Manufacturing Sector in Tanzania: Challenges and the Way Forward," Work. Pap., 2014.

[11] U. A. Mussa, "Industrial development and its role in combating unemployment in Tanzania: history, current situation and future prospects," 2014.

[12] J. Msami and S. Wangwe, "Industrial Development in Tanzania," in Manufacturing Transformation: Comparative Studies of Industrial Development in Africa and Emerging Asia, vol. 6, no. 38, C. Newman, J. Page, J. Rand, A. Shimeles, M. Söderbom, and F. Tarp, Eds. 2016, pp. 45-66.

[13] BOT, Tanzania mainland's 50 years of independence of independence. Dar es Salaam, 2011.
[14] A. Muganda, "Tanzania's Economic Reforms and Lessons," pp. 1-5, 2004.

[15] Ministry of Industry and Trade, Sustainable Industries Development Policy- SIDP (1996-2020). Dar es Salaam, Tanzania: United Republic of Tanzania Printer, 1996.

[16] R. Grabowski, "Deindustrialisation in Africa," pp. 51-67, 2015.

[17] UNICTAD, "The state of industrial development in Africa: unexploited opportunities amidst growing challenges," no. 27, 2013.

[18] F. Tregenna, "Deindustrialisation, structural change and sustainable economic growth," MERIT Work. Pap., no. 32, 2015.

[19] Ministery of Finance and Planning, "Tanzania five year development plan 2016/17 - 2020/21,” Dar es Salaam, 2016.

[20] UNDP, Tanzania Human Development Report 2014. Economic and Social Research Foundation, 2015.

[21] J. Page, "Industry in Tanzania Performance, prospects, and public policy," 2016.

[22] World Bank, "Country Highlights Tanzania 2013,” 2015.

[23] CTI, "The manufacturing sector in Tanzania," 2000.

[24] Ministry of Industry and Trade, "Integrated Industrial Development Strategy 2025," Dar es Salaam, 2011.

[25] UNIDO, “Tanzania Industrial Competitiveness Report 2012," 2012. 